\title{
Clientelism Politics of Muslim Politician Who Became People's Representatives
}

\author{
Mohammad Hidayaturrahman \\ Universitas Wiraja Madura, Indonesia \\ Email: hidayaturrahman@wiraraja.ac.id \\ Doli Witro \\ Universitas Islam Negeri Sunan Gunung Djati Bandung, Indonesia \\ Email: doliwitroo1@gmail.com \\ Ahmad Hasan Ubaid \\ Universitas Brawijaya Malang, Indonesia \\ Email: hasanubaid82@ub.ac.id \\ Tamrin \\ Universitas Andalas Padang, Indonesia \\ Email: tamrin@soc.unand.ac.id \\ Anak Agung Putu Sugiantiningsih \\ Sekolah Tinggi Ilmu Sosial dan Politik Wira Bhakti Bali, Indonesia \\ Email: gektien@gmail.com
}

\begin{abstract}
People's representatives are elected through general elections to represent the people fighting for the people's interests and aspirations. However, in practice, muslim politician who became people's representatives often represent themselves and their groups rather than represent those who have chosen them. This research was conducted to reveal how muslim politician who became people's representatives' actions the correlation between clientelism politics in managing the budget function. This descriptive qualitative research method collects data through direct observation in the field and in-depth interviews with various informants related to the research. The theory used in this research is political clientelism theory. From the research results, muslim politician who became people's representatives fight for the community's aspirations to escort a grant program to community groups, social assistance, and empowerment. The program is directly related to the winning team and
\end{abstract}


M. Hidayaturrahman, D. Witro, A. H Ubaid, Tamrin, A.G.P. Sugiantiningsih

supporters of voters in the previous elections. The program is intended to maintain the people's voting base and the granary in the next election. This is how the people's representative uses the parliament's existence and potential for electoral interests.

Keywords: Muslim Politician, Political Clientelism, People's Representatives.

\begin{abstract}
Abstrak
Wakil rakyat dipilih melalui pemilihan umum untuk mewakili rakyat yang memperjuangkan kepentingan dan aspirasi rakyat. Namun dalam praktiknya, politisi muslim yang menjadi wakil rakyat seringkali mewakili dirinya dan kelompoknya daripada mewakili mereka yang telah memilihnya. Penelitian ini dilakukan untuk mengungkap bagaimana tindakan politikus muslim yang menjadi wakil rakyat korelasi antara politik klientelisme dalam mengelola fungsi anggaran. Metode penelitian kualitatif deskriptif ini mengumpulkan data melalui observasi langsung di lapangan dan wawancara mendalam dengan berbagai informan yang terkait dengan penelitian. Teori yang digunakan dalam penelitian ini adalah teori klientelisme politik. Dari hasil penelitian, politisi muslim yang menjadi wakil rakyat memperjuangkan aspirasi masyarakat untuk mengawal program hibah kepada kelompok masyarakat, bansos, dan pemberdayaan. Program tersebut terkait langsung dengan tim pemenangan dan pendukung pemilih pada pemilu sebelumnya. Program ini dimaksudkan untuk menjaga basis suara dan lumbung suara rakyat pada pemilu mendatang. Beginilah cara wakil rakyat memanfaatkan keberadaan dan potensi parlemen untuk kepentingan elektoral.
\end{abstract}

Kata kunci: Politisi Muslim, Klientelisme Politik, Wakil Rakyat.

\title{
Introduction
}

All policies and regulations made by policy makers must consider the interests and needs of the public (Berlant 2007; Deutsch; Bliss; Eckstein 2018). But in practice, people's sovereignty, people's rights are actually taken away by the authorities and policy makers (Lund 2011). People's representatives are chosen to represent the people in fighting for the aspirations, fate and needs of the people in general (Frączkiewicz-Wronka et al. 2019; Grignon et al. 2020).

Indonesia is one of the democratic countries in the world (Aspinall 2010; Sulistyo 2002). Normatively, democracy in Indonesia has been running since its independence in 1945 in its implementation, democracy in Indonesia does not work strongly (Aswicahyono, Bird, 
and Hill 2009). Ethnic politics still prevail in Indonesia (Aspinall 2011; Nasution 2014). The practice of democracy in Indonesia also does not yet reflect people's sovereignty (Fossati et al. 2020). Democracy in Indonesia is considered more directed towards consolidation towards real democracy (Davidson 2009; Mietzner 2010). Despite the authoritarian New Order regime, Indonesia is still seen as still in the process of consolidating democracy (Larson 2009; Webber 2006).

In a democratic country, representatives of the people have an important role to play in connecting the aspirations and interests of the people (Prihatini 2019). The existence of people's representatives is a manifestation of the involvement of civil society in democracy (Lussier and Fish 2012). Indonesia's democracy is considered to be in a stagnant position, seen from the performance of institutions that should have an orientation to the people (Mietzner 2012). The role of people's representatives in parliament is still questionable. They are still considered not to fight for the people's aspirations, but rather to fight for themselves, their groups and parties (Trijono 2018).

In fact, people's representatives in Indonesia have a clear level. This is an opportunity to make the voices of the people heard more at the regional and central levels (Aspinall 2014a). Moreover, the election of people's representatives in Indonesia no longer uses serial numbers but the majority of votes or known as the open proportional system (Dettman, Pepinsky, and Pierskalla 2017). The logical consequence is that whoever gets the most votes will be the people's representative at every level, whether in the district, province or center. Directly elected representatives are accountable to the voters, especially those in the electoral district (Negri 2018). In fact, the open proportional system gave birth to a climate of corrupt behavior among elected representatives (Riwanto 2015).

The presence of people's representatives at the central and regional levels, does not make their role as a connector to the aspirations and needs of the people optimally accommodated. Very few aspirations and interests and needs of the people represented were accommodated by the people's representatives in parliament. Even if there are programs that are brought by the people's representatives to the electoral area more programs come from above. Made more to the results of compromise with the executive, not a program that really comes from the aspirations of voters at the lower levels (Mujani et al. 2020). The program of absorbing people's aspirations carried out by representatives of the people, commonly called recess, also does not 
produce programs that are popular. Such activities as routine ritual activities, representatives of the people who spend the state budget (Kariem and Ishmatuddin 2020; Rahman and Munaf 2019; Syafruddin; Putra 2019).

The division of labor based on the commission and electoral district also did not go well. People's representatives often only stamp the executive's proposal. Even if there are representatives of the people who are critical of the proposals submitted by the executive can be counted on the fingers. So that the aspirations of the people in the electoral district are often not optimally fought for. The same thing also happened to the legislative function of people's representatives which tended to be suboptimal (Solihah and Witianti 2016).

The political behavior of clientelism is a common phenomenon that occurs in various parts of the world (Daby 2021). The same thing happens to Muslim politicians (Soedirgo 2018), like in Lebanon (Corstange 2018). Clientelism politics also found in the Province of Northern Argentina, where politicians also give goods to voters in the constituency. The items distributed can be goods that can be shared by voters in the electoral district, not just personal. such as in the form of construction projects, the results of which can be shared by residents in the constituency. The size of the development program provided to the electoral district based on proportional consideration of the size of the vote acquisition of politicians in the area (de Rozas 2017). Clientelism politics also took place in rural Brazil (Ansell 2018), in the form of purchasing water tanks for areas experiencing drought (Bobonis; Gertler; Navarro; Nichter 2019), and Papua New Guinea (Kurer 2007). In Iraqi Kurdistan, the Kurdistan Democratic Party and the Patriotic Union of Kurdistan are taking a clientelist approach to gain support. These two parties use public funds for their political interests. in fact, the decisions in the Kurdistan government departments are controlled by them. Opposition parties cannot pressure the ruling party that can buy voters' votes using public funds. This is getting worse at dawn with unfavorable economic conditions, prices of necessities have increased and unemployment has increased (Bali 2018).

Including what happened in Indonesia. The political practice of clientelism in Indonesia occurs in political patrons and clients that occur reciprocally (Hanif 2009). The politics of clientelism in Indonesia also occurs in local politics (Ramadhan, Daniel, and Oley 2019). The same thing also happened in rural areas in Java, Indonesia 
(Berenschot 2018). The politics of clientelism involves money that is managed by the patron and used by the client (Muhtadi 2013).

This research was conducted to describe the correlation between clientelism politics and the actions of the muslim politician who became people's representatives in managing the budget function, of the Sumenep Regency, Madura, East Java, Indonesia. After finding problems relating to the actions of muslim politician who became people's representatives, then analyzed using clientelism politics.

This study uses descriptive qualitative methods by describing the phenomena that occur while analyzing them using clientelism politics. Data collection was carried out at the research location in Sumenep Regency, Madura, East Java, by making direct observations of the ongoing development programs related to road infrastructure, facilities and educational infrastructure, health facilities, transportation facilities, and others such as grants and social assistance programs for farmer groups, fishing groups, cooperatives, and others 2019-2020 period. Assistance can be in nets, fishing equipment, boat engines, sewing machines, and others. It could also be in the form of rehabilitation funds for mosques and prayer rooms.

The researcher also collected data related to programs and activities that have not yet been published in various mass media, print, electronic, and online. The data and documents are in the form of programs in the Sumenep Regency Regional Representative Council (Dewan Perwakilan Rakyat Daerah/ DPRD), both in their respective factions in commissions. Simultaneously, published data are obtained from several locals, regional, and national media, both online, print, and electronic media. The data is then checked by direct observation of the implementation of programs and the results of development programs in the islands.

Data collection was also carried out by conducting in-depth interviews. In-depth interviews were also conducted with those who have an excellent capacity to explain the issues examined in this study. Namely the village head, community leaders, and the general public also people's representatives. In-depth interviews begin with interviews with community leaders and activities that know the activities and activities of people's representatives in the field. The interview results were then matched with the leaders, village heads, the winning team, and the people's representatives themselves. This is done using the triangulation method and re-checked for its mechanism for data collected in the field. 
M. Hidayaturrahman, D. Witro, A. H Ubaid,

Tamrin, A.G.P. Sugiantiningsih

Moreover, the data obtained was double-checked to see if they are in line with the relevant informants. The data collected is not one party, but from many parties and is well verified so that the data obtained and presented are truly accurate.

\section{Results and Discussion}

The people's representatives have one function, namely the functions of budgeting, including members of the Sumenep Regional House of Representatives (DPRD) who are all Muslims. This function allows representatives of the people to be involved in preparing budgets with the executive, regional apparatus organizations (Organisasi Perangkat Daerah/ OPD) in accordance with the leading sector and their respective commissions. The representatives of the people are scattered in various commissions in the Sumenep Regency Regional Representative Council (Dewan Perwakilan Rakyat Daerah/ DPRD) East Java, Indonesia. In carrying out the budgeting function, the people's representatives receive rations and allocation of development funds called the Acceleration of Infrastructure and Poverty Alleviation (Percepatan Infrastruktur dan Pengentasan Kemiskinan/ PIPEK) or the Main Points of the People's Mind (PokokPokok Pemikiran Rakyat/ POKIR). In the last five years, the budget allocation for each representative of the people has also continued to increase the acceleration of PIPEK/ POKIR is used to build infrastructure in Sumenep Regency to reach remote villages, because the submission process is in accordance with what is conveyed by the constituents in respective constituencies, which are then passed on by the people's representatives to the executive.

The role of people's representatives from the archipelago, including the existence of PIPEK/ POKIR rations, apparently has not been able to accelerate infrastructure development. This can be seen from the condition of the main road connecting three sub-districts at the same time in the six constituencies which include the Kangayan, Arjasa and Sapeken districts which were severely damaged. During the rainy season the main and only road is muddy and endangering road users. Damage to road infrastructure is also quite long, covering five villages, starting from the Villages of Pabian, Daandung, JukongJukong, Torjuk and Kangayan. 
Table 1. Funds for the Acceleration of PIPEK/ POKIR DPRD Sumenep

\begin{tabular}{|c|c|c|}
\hline Year & Per member quota & Allocation \\
\hline 2013 & IDR 500.000.000 & $\begin{array}{l}\text { It depends on the board member } \\
\text { who has allotment, what is it used } \\
\text { for. But the program executive } \\
\text { remains executive. People's } \\
\text { representatives propose the form of } \\
\text { program, recipient and place of } \\
\text { implementation. }\end{array}$ \\
\hline 2014 & IDR 750.000.000 & $\begin{array}{l}\text { It depends on the board member } \\
\text { who has allotment, what is it used } \\
\text { for. But the program executive } \\
\text { remains executive. People's } \\
\text { representatives propose the form of } \\
\text { program, recipient and place of } \\
\text { implementation. }\end{array}$ \\
\hline 2015 & IDR 1.000.000.000 & $\begin{array}{l}\text { It depends on the board member } \\
\text { who has allotment, what is it used } \\
\text { for. But the program executive } \\
\text { remains executive. People's } \\
\text { representatives propose the form of } \\
\text { program, recipient and place of } \\
\text { implementation. }\end{array}$ \\
\hline $\begin{array}{l}2016- \\
2020\end{array}$ & IDR 1.200.000.000 & $\begin{array}{l}\text { It depends on the board member } \\
\text { who has allotment, what is it used } \\
\text { for. But the program executive } \\
\text { remains executive. People's } \\
\text { representatives propose the form of } \\
\text { program, recipient and place of } \\
\text { implementation. }\end{array}$ \\
\hline
\end{tabular}

(Source: Interview of several informants, 2020)

The budgeting function that is owned by the people's representatives is not used maximally to fight for programs that are directly related to the livelihood of living together with the citizens of the archipelago, such as repairing roads, educational facilities and infrastructure health, or transportation facilities. The people's representatives oversee grants and social assistance programs in 
various forms, such as fishing nets for fishing groups, sewing machine assistance, workshop equipment assistance, tractor assistance for farmer groups, and various social programs others such as assistance for religious teachers, mosque and musolla rehab assistance. Once again, these programs are of direct benefit to political representatives, as a form of care for constituents.

As well as PIPEK/ POKIR rations owned by representatives of the people, more are used for grant assistance in the form of social assistance, in accordance with the aspirations of constituents or voters. Or in other words given in the form of social assistance as compensation to voters and supporters in the previous elections, as well as to care for their support so that it is possible to remain a loyal voter to next election. PIPEK/ POKIR rations owned by the people's representatives are not used for larger programs and are shared by residents, such as public facilities that can indeed be enjoyed massively by citizens in the electoral district. PIPEK/ POKIR allocation for representatives of the people also continues to increase. Each representative receives more than IDR 1 billion, or equal to IDR 60 billion, in total from 50 people's representatives. There are more leaders than ordinary members. The implementation of PIPEK/ POKIR is left to the executive or the office, but the determination of the location of the implementation and the recipients are determined by the people's representatives.

Instead, there is a mode in implementing PIPEK/ POKIR. There are unscrupulous representatives of the people who "sell" their rations to other constituencies. But PIPEK/ POKIR allocation, not all of them are "sold" to other regions. There are some that continue to be implemented in the electoral district as a form of commitment to constituents and voters. The form is usually in the form of grants and social assistance. But compared to the amount "sold" to other electoral districts the amount is still smaller.

One of the activists of non-governmental organizations (NGOs) in the Sumenep Islands is even more assertive about the rumors of the practice of "buying and selling" PIPEK/ POKIR rations among the people's representatives. "It is common knowledge of such practices." (Suraini interview at his home, March 20, 2019).

Abdullah, the pseudonym of one of the people's representatives in Sumenep Regency, East Java, admitted that his PIPEK/ POKIR program was used for productive business activities. "I use it to revive the community's small businesses, ranging from planting banana 
trees, tofu businesses, brick making businesses, and many others. As for other board members, I cannot comment on my colleagues." (Interview, at his home, November 9, 2019). Another people's representative who came from the archipelago, Ahmad, a pseudonym, even asked to be mentioned if there were representatives of the people not to "sell" the PIPEK or POKIR program that became their quota. "I want to know who is trying to not sell the ration?" (Interview at Cafe Java Inn, 17 October 2019). What was conveyed by the two representatives was not much different from the recognition of one of the village heads who subscribed to "buy" the PIPEK/ POKIR program offered by the people's representatives. "It can be normal every year, with compensation of up to 30 percent of the value of the program, sometimes paid at the beginning sometimes after the program goes down." (Interview, Hasan, name disguised, one of the heads in the Sumenep Islands, East Java at the village hall, 2 July 2019).

Rahmad, one of the former people's representative winning teams in the Sumenep Islands admitted that the practice of "buying and selling" the program was not solely because the people's representatives offered, but because there was indeed a request from the public or government officials lower level. "Yes indeed sometimes there are also those who deliberately look for the program, and dare with a large percentage, yes of course they can also profit." (Interview at his home, 5 June 2019).

The program model carried out by people's representatives like this is called by Aspinall as clientelism politics (Allen 2015; Aspinall 2014b). The clientelism political model is a culture that is prevalent among politicians in Indonesia and several other democracies in the world. Both actors and voters feel that this is normal (Bedran-Martins and Lemos 2017; Frey 2019). Berenschot (2018) argued that clientelism politics is a political practice which refers to the provision of assistance provided by politicians to voters. assistance can be in the form of money, welfare benefits, employment, contracts, etc. in return for voters to provide electoral support. Robinson \& Verdier (2013) said the practice of clientelism is a political exchange, politicians (political actors) provide protection (assistance) in return for support or votes obtained from voters. clientelism politics takes many forms depending on the focus, scale and context. Bénit-Gbaffou (2011) arguing that clientelism politics is a form of exchange between voters and politicians in the form of political support from voters and public goods (assistance) provided by politicians. The relationship that 
occurs in clientelism politics is not only for two people who are personalized between the two parties, but will also develop between politicians and a group called collective clientelism. In addition, the practice of clientelism also involves the distribution of public goods, in the form of access to social services, work contracts, and public housing. clientelism politics is not just about voting, or political support, but can take other forms such as taking part in party rallies or representing parties in public or local meetings, one might say clientelism politics.

In Sumenep, Madura Jawa Timur, Indonesia muslim politician who became people's representatives carry out programs solely to get votes from voters. Not doing something because it is indeed the responsibility that is assumed as the people's representative. So that what is done by the people's representatives, will still consider the electoral impact obtained by the people's representatives from the programs carried out and the recipients of assistance. In the context of the role of the people's representatives in the electoral district reflects the role of political gains or benefits, rather than the role of development. As a political actor it is certainly a natural thing. Seen from program advocacy carried out more oriented to programs that are grants and social assistance. Grant programs and social assistance are usually received by close people, winning teams or people who help them in the winning process. This is part of the way people's representatives care for supporters and the winning team. In Indonesia, in the 2019 general election, each regional representative candidate spent around IDR 2-3 billion on average. "I used to run as a people's representative, didn't have the capital, I didn't. After that I worked for Jakarta, and I returned with billions of money, I used it to run again, and I won." (Delivered by Khalid, the people's representative in Sumenep, East Java, Indonesia, at the Wiraraja University Campus, 10 October 2020).

In Indonesia, every general election of candidates for representatives of the people relies on buying support from parties and voters Berenschot (2018). So that candidates for representatives of the people in Indonesia need a large amount of funds. In order to obtain funds, it is not uncommon for political actors to seek funding from the private sector, and the practice of clientelism politics occurs. (Gherghina and Volintiru 2017). In Indonesia political actors build campaign networks and build connections with religious leaders, wealthy businessmen and local bureaucrats. here often occurs 
clientelism politics made by politicians, by providing social assistance, free medical treatment, and others (Latief 2014).

Clientelism politics does not only occur in Indonesia. In various parts of other countries that embrace democracy the same thing happens. those who have power tend to use state resources for shortterm political interests, electoral interests only. As is also the case in India, which spends a lot on the state budget in the form of goods purchases, in electoral districts which are the basis for voters in the ruling party or those who win at the time of contestation. Of course for the purpose of getting a vote at the next general election (Bhavnani and Jensenius 2019). Clientelism has also occurred in China during Xi Jinping's administration since power took over in late 2012(Doyon 2018). In Ghana, clientelism politics has led to many physical development programs, such as schools and other public facilities that have not been completed and left undone, as a result of clientelist political behavior (Williams 2017).

Clientelist political research has developed in various parts of the world, such as South America, Africa, Asia, and Eastern Europe. In general, the existence of democratization makes clientelist politics less exploitative, but its development cannot be said to be not widespread (Berenschot 2018). The politics of clientelism generally occur in developing countries (Rocha, Souza, and Araújo 2019). Without denying this also happened to developed countries. Stokes, Dunning, Nazareno, \& Brusco (2013) suggest that poor countries are more prone to clientelist politics. When voters are poor, the potential for engaging in clientelist politics will be even greater. society is very dependent on social assistance from politicians, so with a little persuasion from politicians they are easily deceived.

Political clientelism in practice often has another effect, namely corruption. Although the two are theoretically separate, there are still intersections (Gherghina and Volintiru 2017). This happened in Sumenep, East Java, Indonesia, which was carried out by representatives of the people. There are unscrupulous representatives of the people who "sell" their rations to other constituencies. But PIPEK/ POKIR allocation, not all of them are "sold" to other regions. There are some that continue to be implemented in the electoral district as a form of commitment to constituents and voters. The form is usually in the form of grants and social assistance. But compared to the amount "sold" to other electoral districts the amount is still smaller. 
Tamrin, A.G.P. Sugiantiningsih

Clientelism and corruption are closely related to resources. The state collects resources by means of loans or public taxation, before politicians who are representatives of the people and economic actors of their allies takeover to be distributed to the public through the clientelist system (Trantidis and Tsagkroni 2017). Furthermore, clientelist politics is often used as a strategy for vote buying. In this context, the involvement of the private sector is of great benefit to those who need a voice. economic actors are allies of politicians in clientelist politics to be the parties who are the funders. Private funding has a significant role to play in voter vote buying (Gherghina and Volintiru 2017). This kind of practice in turn comes at the expense of existing resources. Furthermore, the impact is not good for a country's economic growth. However, this strategy is electorally effective (Keefer 2005; Wantchekon 2003). This only benefits political actors and those who are funders. As happened in several countries on the African continent, vote buying and clientelism have become structural phenomena, part of the local political culture, and have even entered the political stage of the African continent in general (Vicente and Wantchekon 2009).

The research on the political form of clientelism conducted by the members of the Regional House of Representatives of Sumenep Regency, Madura is by utilizing the state budget in the form of POKIR, by distributing programs to the winning team and people who support them when the people's representatives are running for the general election. If it is given to other parties, then they will ask for a fee of $30 \%$ of the amount given. Giving the program to the winning team and people who have helped it in the general election is an effort to nurture them to help again in the next general election. The 30\% fee obtained is also used to finance the next general election.

\section{Conclusion}

The muslim politician who became people's representatives in Sumenep, Madura, East Java practice clientelist politics when they serve as representatives of the people. This is done to maintain the continuity of their office and to gain office in the next election. The way this is done is by using the state budget through the budget function, by participating in determining the recipients of social assistance and social programs originating from the Regional Revenue and Expenditure Budget (Anggaran Pendapatan dan Belanja Daerah/ 
APBD). Was mostly carried out in the form of escorting social assistance programs and grants, such as net assistance for fishing groups, workshop equipment assistance, sewing machine assistance, assistance for religious teachers, musolla assistance, farmer group assistance, village road, and others. The program is intended to maintain the people's voting base. Of course, will be the granary in the next election. This is how the existence and potential of parliament are used by the people's representatives for electoral interests.

\section{REFERENCES}

Allen, Nathan W. 2015. Clientelism and the Personal Vote in Indonesia. Electoral Studies 37: 73-85. http://dx.doi.org/10.1016/j.electstud.2014.10.005.

Ansell, Aaron. 2018. Clientelism, Elections, and the Dialectic of Numerical People in Northeast Brazil. Current Anthropology 59(S18): S128-37.

Aspinall, Edward. 2010. The Irony of Success. Journal of Democracy 21(2): 20-34.

Aspinall, Edward. 2011. Democratization and Ethnic Politics in Indonesia: Nine Theses. Journal of East Asian Studies 11(2): 289-319.

Aspinall, Edward. 2014. Parliament and Patronage. Journal of Democracy 25(4): 96-110.

Aspinall, Edward. 2014. When Brokers Betray: Clientelism, Social Networks, and Electoral Politics in Indonesia. Critical Asian Studies 46(4): 545-70.

Aswicahyono, Haryo, Kelly Bird, and Hal Hill. 2009. Making Economic Policy in Weak, Democratic, Post-Crisis States: An Indonesian Case Study. World Development 37(2): 354-70. http://dx.doi.org/10.1016/j.worlddev.2008.06.007.

Bali, Ahmed Omar. 2018. The Roots of Clientelism in Iraqi Kurdistan and the Efforts to Fight It. Open Political Science 1(1): 98-104. 
M. Hidayaturrahman, D. Witro, A. H Ubaid,

Tamrin, A.G.P. Sugiantiningsih

Bedran-Martins, Ana Maria, and Maria Carmen Lemos. 2017. Politics of Drought under Bolsa Família Program in Northeast Brazil. World Development Perspectives 7-8(March): $15^{-21 .}$ https://doi.org/10.1016/j.wdp.2017.10.003.

Bénit-Gbaffou, Claire. 2011. Up Close and Personal' - How Does Local Democracy Help the Poor Access the State? Stories of Accountability and Clientelism in Johannesburg. Journal of Asian and African Studies 46(5): 453-64.

Berenschot, Ward. 2018. The Political Economy of Clientelism: A Comparative Study of Indonesia's Patronage Democracy. Comparative Political Studies 51(12): 1563-93.

Berlant, Lauren. 2007. Slow Death (Sovereignty, Obesity, Lateral Agency). Critical Inquiry 33(4): 754-80.

Bhavnani, Rikhil R., and Francesca R. Jensenius. 2019. Voting for Development? Ruling Coalitions and Literacy in India. Electoral Studies 102069. https://doi.org/10.1016/j.electstud.2019.102069.

Bobonis; Gertler; Navarro; Nichter. 2019. Vulnerability and Clientelism. National Bureau of Economic Research: 1-37.

Corstange, Daniel. 2018. Clientelism in Competitive and Uncompetitive Elections. Comparative Political Studies 51(1): 76-104.

Daby, Mariela. 2021. The Gender Gap in Political Clientelism: Problem-Solving Networks and the Division of Political Work in Argentina. Comparative Political Studies 54(2): 215-44.

Davidson, Jamie S. 2009. Dilemmas of Democratic Consolidation in Indonesia. Pacific Review 22(3): 293-310.

Dettman, Sebastian, Thomas B. Pepinsky, and Jan H. Pierskalla. 2017. Incumbency Advantage and Candidate Characteristics in Open-List Proportional Representation Systems: Evidence from Indonesia. Electoral Studies 48: 111-20. http://dx.doi.org/10.1016/j.electstud.2017.06.002. 
Deutsch; Bliss; Eckstein. 2018. Population, Sovereignty, and The Share of Foreign Trade. World Politics: $353-67$.

Doyon, Jérôme. 2018. Clientelism by Design: Personnel Politics under Xi Jinping. Journal of Current Chinese Affairs 47(3): 87-110.

Fossati, Diego, Edward Aspinall, Burhanuddin Muhtadi, and Eve Warburton. 2020. Ideological Representation in Clientelistic Democracies: The Indonesian Case. Electoral Studies 63. November 2019):

102111. https://doi.org/10.1016/j.electstud.2019.102111.

Frączkiewicz-Wronka, Aldona, Iwona Kowalska-Bobko, Anna Sagan, and Martyna Wronka-Pośpiech. 2019. The Growing Role of Seniors Councils in Health Policy-Making for Older People in Poland. Health Policy 123(10): 906-11.

Frey, Anderson. 2019. Cash Transfers, Clientelism, and Political Enfranchisement: Evidence from Brazil. Journal of Public Economics 176: $1-17$. https://doi.org/10.1016/j.jpubeco.2019.05.002.

Gherghina, Sergiu, and Clara Volintiru. 2017. A New Model of Clientelism: Political Parties, Public Resources, and Private Contributors. European Political Science Review 9(1): 115-37.

Grignon, M., C. J. Longo, G. P. Marchildon, and S. Officer. 2020. The 2018 Decision to Establish an Advisory Council on Adding Pharmaceuticals to Universal Health Coverage in Canada. Health Policy 124(1): 7-11. https://doi.org/10.1016/j.healthpol.2019.10.006.

Hanif, Hasrul. 2009. Politik Klientelisme Baru Dan Dilema Demokratisasi Di Indonesia . JSP: Jurnal Ilmu Sosial dan Ilmu Politik 12(3): 257-390.

Kariem, Muhammad Quranul, and Noor Ishmatuddin. 2020. Analysis of the Legislative Function of Banyuasin Regency Legislative Council Members during the Recess Period. Journal of Governance and Public Policy 7(1): 29-34. 
M. Hidayaturrahman, D. Witro, A. H Ubaid,

Tamrin, A.G.P. Sugiantiningsih

Keefer, Philip. 2005. Democratization and Clientelism: Why Are Young Democracies Badly Governed? (3594).

Kurer, Oskar. 2007. Why Do Papua New Guinean Voters Opt for Clientelism? Democracy and Governance in a Fragile State. Pacific Economic Bulletin 22(1): 39-53.

Larson, Brooke. 2009. 13 Democratic Deficits. Addressing challenges to sustainability and Consolidation around the world Democratic Deficits Addressing Challenges to Sustainability and Consolidation Around the World. ed. Gary Bland and Cynthia J. Arnson. Washington: Woodrow Wilson International Center for Scholars. http://www.ncbi.nlm.nih.gov/pubmed/22106744.

Latief, Hilman. 2014. The Politics of Benevolence: Political Patronage of Party-Based Charitable Organizations in Contemporary Indonesian Islam. Al-Jami'ah 51(2): 337-63.

Lund, Christian. 2011. Fragmented Sovereignty: Land Reform and Dispossession in Laos. Journal of Peasant Studies 38(4): 885905 .

Lussier, Danielle N., and M. Steven Fish. 2012. Indonesia: The Benefits of Civic Engagement. Journal of Democracy 23(1): 7084.

Mietzner, Marcus. 2010. Political Conflict Resolution and Democratic Consolidation in Indonesia: The Role of the Constitutional Court. Journal of East Asian Studies 10(3): 397-424.

-_ 2012. Indonesia's Democratic Stagnation: Anti-Reformist Elites and Resilient Civil Society. Democratization 19(2):20929.

Muhtadi, Burhanuddin. 2013. Money Politic Dalam Pemilu Menurut Pandangan ukum Islam Dan Undang-Undang. Jurnal Penelitian Politik 11(1): 45.

Mujani, Saiful, R William Liddle, Saiful Mujani, and R William Liddle. 2020. Indonesia : Personalities, Parties, and Voters 
Parties , and Voters. 21(2): 35-49.

Nasution, Indra Kesuma. 2014. Ethnicity, Democracy and Decentralization: Explaining the Ethnic Political Participation of Direct Election in Medan 2010. Procedia Environmental Sciences 20:

http://dx.doi.org/10.1016/j.proenv.2014.03.062. 496-505.

Negri, Margherita. 2018. Preferential Votes and Minority Representation in Open List Proportional Representation Systems. Social Choice and Welfare 50(2): 281-303.

Prihatini, Ella S. 2019. Women's Views and Experiences of Accessing National Parliament: Evidence from Indonesia. Women's Studies International Forum 74(December 2018): 84-90. https://doi.org/10.1016/j.wsif.2019.03.001.

Rahman, Oki, and Yusri Munaf. 2019. Dewan Perwakilan Rakyat Daerah Kota Pekanbaru Periode 2009-2014. Wedana: 201-11.

Ramadhan, Muhammad Nur, Jimmy Daniel, and Berlianto Oley. 2019. Klientelisme Sebagai Perilaku Koruptif Dan Demokrasi Banal. Jurnal Antikorupsi Integritas 5(1): 169-80. https://jurnal.kpk.go.id/index.php/integritas/article/view/379.

Riwanto, Agus. 2015. Korelasi Pengaturan Sistem Pemilu Proporsional Terbuka Berbasis Suara Terbanyak Dengan Korupsi Politik Di Indonesia. Yustisia Jurnal Hukum 91(1): 89102.

Robinson, James A., and Thierry Verdier. 2013. The Political Economy of Clientelism. Scandinavian Journal of Economics 115(2): 260-91.

Rocha, Marta Mendes, Augusto Carvalho de Souza, and Paulo Magalhães Araújo. 2019. Clientelism and Local Politics: Interactions Between Municipal Councilors and Voters in the State of Minas Gerais. Brazilian Political Science Review 13(3): $1-33$.

de Rozas, Victoria Ortiz. 2017. Clientelismo o Representación 
Política? El 'Programa' de Los Mediadores Políticos. Reflexiones Desde Argentina. Revista Mexicana de Ciencias Politicas y Sociales 62(229): 263-96. http://dx.doi.org/10.1016/So1851918(17)30011-9.

Soedirgo, Jessica. 2018. Informal Networks and Religious Intolerance: How Clientelism Incentivizes the Discrimination of the Ahmadiyah in Indonesia. Citizenship Studies 22(2): 191-207. https://doi.org/10.1080/13621025.2018.1445490.

Solihah, Ratnia, and Siti Witianti. 2016. Pelaksanaan Fungsi Legislasi

Dewan Perwakilan Rakyat Pasca Pemilu 2014: Permasalahan Dan Upaya Mengatasinya. CosmoGov 2(2): 291.

Stokes, Susan C., Thad Dunning, Marcelo Nazareno, and Valeria Brusco. 2013. Brokers, Voters, and Clientelism. Cambridge: Cambridge University Press.

Sulistyo, Hermawan. 2002. Electoral Politics in Indonesia: A Hard Way to Democracy. Croissant/Bruns/John: 75-10o.

Syafruddin; Putra. 2019. Efektivitas Reses Anggota DPRD Dalam Menyerap Aspirasi Masyarakat Tahun Anggaran 2018. Politicon 8(2): 53-65.

Trantidis, Aris, and Vasiliki Tsagkroni. 2017. Clientelism and Corruption: Institutional Adaptation of State Capture Strategies in View of Resource Scarcity in Greece. The British Journal of Politics and International Relations 19(2): 263-81.

Trijono, Rachmat. 2018. Is the Republic of Indonesia As a Democratic State? (Case Study the Republic of Indonesia Representative Democracy Model in Perspective of Law Making Process). PEOPLE: International Journal of Social Sciences 4(3): 44-56.

Vicente, Pedro C., and Leonard Wantchekon. 2009. Clientelism and Vote Buying: Lessons from Field Experiments in African Elections. Oxford Review of Economic Policy 25(2): 292-305.

Wantchekon, Leonard. 2003. Clientelism and Voting Behavior: Evidence from a Field Experiment in Benin. World Politics 
55(3): 399-422.

Webber, Douglas. 2006. A Consolidated Patrimonial Democracy? Democratization in Post-Suharto Indonesia. Democratization 13(3): 396-420.

Williams, Martin J. 2017. The Political Economy of Unfinished Development Projects: Corruption, Clientelism, or Collective Choice? American Political Science Review 111(4): 705-23. 